\title{
To End a Civil War: Norway's Peace Engagement in
}

\section{Sri Lanka}

\section{Mark Salter}

\section{London: Hurst \& Company, 2015}

Anmeldt av Ada Nissen ${ }^{\star}$,

PhD $i$ historie

Våren 2009, etter nesten ti år med aktiv meglingsinnsats, tok Norges fredsengasjement i Sri Lanka slutt da srilankiske regjeringsstyrker nedkjempet de tamilske tigrene militært. Fredsprosessen som skulle resultere i en bærekraftig og inkluderende avtale endte i stedet i full krig der tusenvis av sivile døde. Hvordan kunne det gå så galt?

Historier og analyser av varierende kvalitet har florert både i Sri Lanka, Norge og internasjonalt. Mediene har spunnet fortellinger i sprikende retninger. Forskningen på området har vært mer sober, men har i flere tilfeller truffet konklusjoner som de involverte aktørene ikke kjenner seg igjen i. Derfor lanserer nå meglerduoen Erik Solheim og Vidar Helgesens sin version av historien. To End A Civil War, Norway's Peace Engagement in Sri Lanka er et resultat av Solheim og Helgesens ønske om å bringe klarhet i det hele, «to set the record straight» (8) som bokens forfatter, den erfarne britiske utenriksjournalisten Mark Salter, skriver innledningsvis. Boken er finansiert av norsk UD og forklarer ifølge forlaget hvordan Norge fikk rollen som tredjepart, og hva det norske meglerteamet «in their untiring efforts» gjorde for å oppnå en fredsavtale. I elleve kapitler forteller Salter med stor kunnskap og detaljrikdom om prosessens utvikling fra den spede begynnelsen på 1990-tallet til den blodige avslutningen i 2009. I kapittel tolv, bokens siste kapittel, presenteres «Lessons Learned», før en epilog oppsummerer situasjonen i Sri Lanka etter krigens slutt.

Salter understreker innledningsvis at dette ikke er en akademisk bok. Spørsmålet blir da hvilken sjanger den tilhører og hvilket publikum den retter seg mot. To End a Civil War beveger seg nemlig $\mathrm{i}$ et spesielt sjangerlandskap med elementer fra forskningslitteratur, memoarer og journalistikk. Andre bøker i denne kategorien er for eksempel Odd Karsten Tveits Krig og diplomati - Oslo - Ferusalem 1978-96 (2005), og Hilde Frafjord Johnsons Waging Peace in Sudan (2011). Journalister eller aktører forteller altså historien om politiske prosesser slik de selv, eller aktører de har

^Korrespondanse: Ada Nissen. Email: a.e.nissen@ikah.uio.no 
intervjuet, husker den. Denne typen framstillinger er ofte informative, detaljerte og appellerende. Dette skyldes ikke minst at de er basert på involverte aktørers unike erfaringer. Samtidig er det en rekke utfordringer knyttet til dem. Nettopp fordi fortelleren selv, eller de historien fortelles på vegne av, er protagonistene vil framstillingene alltid være personlige og selektive i sine tolkninger av hendelser, aktører og handlingsmønstre. Personlig motivasjon for å fortelle historien på en bestemt måte er en nøkkelfaktor her.

Mark Salter er åpenbart både kunnskapsrik og god til å fortelle. Den svært detaljrike historien utfolder seg kronologisk, og for en som kjenner historien og persongalleriet fra før er det relativt greit å henge med. Spørsmålet er imidlertid om lesere som er mindre kjent med Sri Lanka og konflikten, vil oppleve det på samme måte. Antallet aktører og hendelser er enormt. Ettersom dette ikke er en akademisk bok antar jeg at den derfor retter seg mot alt fra diplomater, politikere og bistandsarbeidere til journalister og allment opplyste lesere med interesse for Sri Lanka og/eller internasjonal politikk. Det er altså for dette publikummet boken skal bringe større klarhet. Detalinivået antyder at Salter etterstreber nøyaktighet, men tettheten av navn, datoer og steder kan for mange lesere trolig også virke forvirrende.

Bokens viktigste fortellergrep er å la involverte aktører og ulike observatører snakke selv. I egne tekstbokser forteller disse hyppig om sine syn på hendelser, beslutninger og andre aktører. Grepet har den åpenbare funksjon at stemmene til bokens initiativtakere og hovedaktører Erik Solheim og Vidar Helgesen kommer tydelig frem. Også andre sentrale aktører som tidligere president Chandrika Kumaratunga og tidligere statsminister Ranil Wickremesinghe får heve stemmen. Å la aktørene selv komme til orde er i utgangspunktet noe jeg som historiker i prinsippet har stor sans for. Likevel er grepet i dette tilfellet problematisk. For det første er det uheldig at aktørene ikke introduseres med annet enn navn i hver tekstboks. Dette forutsetter at leseren hele tiden vet eller husker hvem aktørene er og i hvilken kapasitet de snakker, og gjør dermed lesingen krevende. Bakerst i boken finnes en oversikt over intervjuobjektene, men sitatene kommer så tett at det er en prøvelse å stadig måtte bla fram og tilbake. Selv en forsker som kjenner persongalleriet og historien godt blir forvirret. For hvem var danske Susanne Ringaard Pedersen igjen? Hva betyr det egentlig at president Kumaratunga er kritisk til Norge på flere punkter? (163). Og hva i all verden betyr det at D.B.S. Jeyaraj, som ikke en gang står i intervjuregisteret og som leseren dermed overhodet ikke kan vite at er en erfaren tamilsk journalist, mener om den srilankiske regjeringen og LTTEs felles koordineringsplan for opprydningsarbeidet etter tsunamien i 2004 ?

Jeg tror Salter overvurderer leserens evne til å sortere og vurdere alle uttalelsene til srilankiske politikere, diplomater, akademikere og journalister, indiske redaktører, norske diplomater, amerikanske diplomater, svenske akademikere og danske observatører. Det er ikke utvalget av informanter det står på. Problemet er at informantenes uttalelser blir hengende i løse luften uten at de følges opp med kommentarer eller analyser. Hensikten er åpenbart å unngå at forfatteren opptrer som overdommer. Men å forvente at leseren skal klare å pusle alle bitene sammen til den store klarheten er for mye forlangt. 
Et relatert problem handler om hvilke krav man kan stille til kildebruk og analyser i en bok som denne. Sjangeren åpner nemlig for bruk av litterære grep som til tider kan minne om romanens. Når Salters intervjuobjekter snakker er fortidige utsagn og dialoger flere ganger rekonstruert (for eksempel 21, 113, 163-164, 284-285.) I et tilfelle er fortellingen om politikk i indiske Tamil Nadu på 1980-tallet til og med basert på Erik Solheims minne om LTTEs avdøde sjefsideolog Anton Balasinghams minne (16). Dette er problematisk både fordi informasjonen er toleddet og fordi den menneskelige hukommelsen er i stadig forandring. Minner kan være uklare og noen ganger også ukorrekte. Nå er selvfølgelig denne problematikken som regel noe faghistorikeren beskjeftiger seg mer med enn journalisten. Men ettersom To End a Civil War tar mål av seg å bringe økt klarhet i fortellingen om Norges rolle i Sri Lanka, forventer jeg at opplysninger og tolkninger som framkommer gjennom aktørenes stemmer diskuteres $\mathrm{i}$ lys av enten annet kildemateriale eller annen litteratur. For som historiker Paula S. Fass formulerer det i sin artikkel The Memoir Problem fra 2006: «[T] he lust to write and the desire for fame can exact deep costs for historical accuracy.» ${ }^{1}$

En viktig forskjell mellom boken til Salter og bøkene til Odd Karsten Tveit og Hilde Frafjord Johnson er at sistnevnte i tillegg til intervjuer støtter seg på et rikholdig kildemateriale fra norsk UD. De fleste internasjonale journalister kan ikke lese norsk, og kan dermed heller ikke forventes å bruke norsk arkivmateriale. Likevel er fraværet av norske kilder en svakhet, ettersom boken tross alt forteller historien om Norges rolle. Gjennom fortellingen støtter Salter seg sporadisk til offentlige dokumenter fra FN og USA, samt enkelte amerikanske Wikileaksdokumenter. Boken har også en relativt rikholdig litteraturliste som inkluderer både bøker, rapporter og avisartikler. Verken dokumentene eller litteraturen blir imidlertid brukt aktivt for å understøtte eller korrigere påstander, tolkninger og analyser som framkommer i intervjuene. I siste kapittel lufter aktører, forskere og journalister sine tanker om hvilke lærdommer som kan trekkes av prosessen. En rekke interessante og nyttige refleksjoner om kloke og mindre kloke valg fremkommer. Men nok en gang blir det opp til leseren å systematisere, vurdere og pusle sammen bitene til det store bildet, eller klarheten som bokens initiativtakere ønsker å bidra til. Dette setter nok en gang svært høye, om ikke urimelige krav til leseren.

To End a Civil War er et velkomment bidrag til historien om fredsprosessen i Sri Lanka. Men jeg er usikker på om Salter, Solheim og Helgesen når målet om å bringe større klarhet i fortellingen, "to set the record straight» som Salter skriver. Bokens kildebruk, og fravær av systematisk diskusjon giør det vanskelig å forstå hvilke utfordringer og problemer som var de største, hvilke man bør feste seg ved og hvilke som kanskje ikke er like interessante. Dermed blir det også vrient for leseren å forstå på hvilke punkter Norge primært har fått kritikk og hvorfor. Mest bemerkelsesverdig av alt er det kanskje at UD og Norads eget bestillingsverk, rapporten Pawns of Peace, Evaluation of Norwegian Peace Efforts in Sri Lanka, 19972009 (2011) er skrevet fullstendig ut av historien. Det finnes ikke en eneste referanse til rapporten i løpet av bokens 529 sider. Selv om de norske aktørene var uenige i

\footnotetext{
${ }^{1}$ Paula S. Fass, «The Memoir Problem», Reviews in American History 34, no. 1 (2006), 121.
} 
Ada Nissen

enkelte av rapportens konklusjoner, må man kunne forvente at en seriøs bok om Norges rolle i Sri Lanka forholder seg til resultater truffet av et internasjonalt forskerteam. Rapporten er basert på grundige undersøkelser og vurderinger av prosessen, inkludert intervjuer og en omhyggelig gjennomgang av norsk kildemateriale. Ikke minst er dette vesentlig all den tid bokens tittel like gjerne kunne ha vært «How Not to End a Civil War». 